\title{
The Visit of Philip II
}

T $\mathrm{T}$ is somewhat curious that English historians, in describing an 1 event franght with such tremendous possibilities to Christianity as the coming of the Spanish prince to wed Mary of England, should have entirely overlooked a.source of information which was more likely than any other to abound in interesting and trustworthy détails of the voyage-I mean the contemporary narratives of Spaniards who accompanied Philip hither. So far as regards the splendid pageantry that marked the new consort's entrance into London the English records themselves leave nothing to be desired. Darnley's tutor, John Elder, in his letter to his pupil's uncle, the bishop of Caithness, ${ }^{1}$ descends to the minutest particulars, and is amply confirmed by the anonymous chronicle of Queen Mary in the Harleian manuscripts, whence John Stow derived his information , by Edward Underhyll, 'the hot-gospeller,' and the letters of the French ambassador Antoine de Noailles." The gorgeous ceremonies that attended the marriage in Winchester Cathedral are also sufficiently described by these and other outhorities, as well as in the official account of the English heralds of the time, copied from the Book of Precedents of Ralph Brooke, York herald, and printed in Leland's 'Collectanea,' edit. 1774, and by the Camden

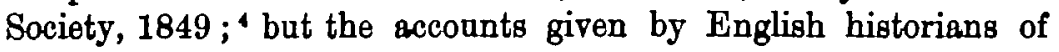
Philip's voyage and reception at 'Southampton appear to rest entirely upon a narrative of an Italian nemed Baosrdo, published in Venice in 1558, four years after the event, and the letters of Noailles to the king of France. Miss Strickland and Mr. Froude, both of whom draw apon Baoardo to a large extent for their local colour, quote him as an eye-witness of the scenes he describes. Whether he was so or not I do not know, although I have been

1 This curious and rare tract was reprinted by the Camden Society, 1849, and is the gronndwork of Foxe's and Hollingshed's accounts of the events related therein.

I Edward Underbyll was one of the gentlemen pensionera, and his quaint narrative of the accession of Mary and the subsequent erents, now amongst the Harleian manuacripts, was largely nood by Btrype and others.

Ambassades do Noailles. Ieyden, 1763.

+ To these may be added the slight but interesting narrative existing in manuscript at Louvain, snd printed by Tytler in his Edward VI and Mary, and the letters of the Venetian ambassador in Flanders to the doge and senate, for which soe Calendar of Stak Papers (Venetian) of the date in question. 
unable to discover any evidence of his presence, but in any case the bitter animus against Philip shown in his narrative is so clear that it is unfair to accept his statements without ample confirmation.

Such confirmation seems to have been sought, by Mr. Froude at all events, in the letters of the French ambassador, and from this material, coupled with the fact that certain pradent measures of precaution were suggested by Simon Renard, the emperor's ambassador, in his letters to his master, the historian paints his highly coloured picture of Philip as a sulky, sea-sick craven trembling at his very shadow, in momentary fear of poison, consummating a sacrifice from which his soul revolts. To justify this view Mr. Froude depends mainly upon Noailles. It must, however, be remembered first, that the French nmbassador was not in a position to know the exact details of Philip's voyage and reception : secondly, that he was the last person in the world to give a fair account of them ; thirdly, thet the historian has gone beyond his authority, even such as it was; and fourthly, that several witnesses of the events described, whose evidence has hitherto been ignored, entirely fail to confirm the view taken by Mr. Froude from Noailles and Baoardo. Throughout the whole negotiations that had preceded the arrangement of the marriage Noailles had been absurdly illinformed and wide of the mark. ${ }^{5}$ His letters to the king of France and the constable teem with predictions and assertions which subs-aquent events proved to be quite wrong, and it is easy to see that for months previous to the marriage he was entirely hoodwinked and out of touch with trustworthy sources of information. In a letter to the French adviser of Mary of Lorraine in Scotland, M.

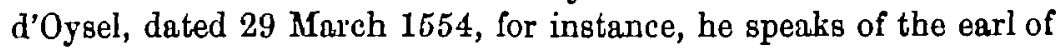
Bedford's departure for Spain as an accomplished fact, and has no doubt that he had already sailed from Plymouth to fetch the prince. On May 18, after ringing the changes upon this for nearly two months, he tells the king that the rumour runs that Bedford is to go shortly to Spain, but that the prince will not come until the winter, whereas Philip had already left Valladolid at the time on his way to England. On 31 March Noailles is quite persuaded that Wyatt's life will be spared, and less than a fortnight later he describes his execution. On $29 \mathrm{March}$, again, he says that the bishop of Norwich, the queen's ambassador to the emperor, had been summoned to perform the marriage, and was to be created archlishop of York for the purpose. Gardiner, bishop of Winchester, really performed the ceremony. Noailles again is quite sure that other Wyatts will arise

- He was equally at sea at the beginning of Mary's reign, when he vigorously aided Northumberland's conspiracy to place Lady Jane Grey on the throne, and repeatedly told his master that Mary's canse was an absolutely hopeless one. On the ignominious collspse of Dadley, Noailles excused his own want of prescience by saying that nothing but a direct miracle from hearen could harc brought about sach a change. 
and that 50,000 men will be in arms to receive the prince, and in April, after writing for weeks of the preparations for the arrival of Philip on the south coast and marriage at Winchester, he believes it all to be a feint and that the prince will suddenly appear and be married in London. On the 29th of the same month he is strongly of opinion that Sir James Crofts will be executed on the following Monday, whereas that distinguished old soldier lived and fought for many years afterwards. Hardly a letter, indeed, from Noailles at this period fails to show that the man, having been completely outwitted by Renard's keen diplomacy, was entirely at sea and badly served by his informers. But I go beyond this. Philip had anchored in Southampton Water on the afternoon of 19 July 1554, and landed on that of the 20th. On the night of the 20th, after the prince had landed, Noailles learnt in London by an imperial messenger for the first time of his arrival, and communicated the news to the king of France immediately by letter; and on the 23rd he writes-

J'ai envoyé ung des miens a Hamptonne et ì Winchestre et despescheray demain encores ung aultre pour estre mieulx par mesme informé de tont ce qui se fera tant ì la terre que sur la mer . . . affin de tenir advertye vostre majesté.

It is clear, thercfore, that Noailles had no trustworthy person to give an exact account of the reception of the prince until the arrival of the latter at Winchester, and the description in his letters of Plilip's royage and doings at Southampton was merely current gossip dressed up to suit the palate of the writer and his master." How much impartiality could be expected from Noailles under the circumstances may well be imagined. He had been thoroughly outmanœuvred, und French diplomacy had received a greater blow than it had sustained for many years in seeing England drift apparently for good into the arms of Spain. His country was at the very moment engaged in a long and costly war with the emperor, and he hinself had just been detected and exposed for the second time in his attewpts to suborn and support rebellion in England, and was in high dudgeon at being pointedly excluded from participation in the marriage festivities. What wonder, then, that after slandering the queen for months past he should do as much as possible to darken the shadows of the picture of Philip sent for the delectation of Philip's enemy? It were expecting too much to

- I am of conrse afaro that the ambassador had eeat his brother Francois de Nonilles to re:puest the queen to stand godmother to his newly born son, but Francois only arrived at Winchester from London on the day the queen received news of the arrival of the prince off the Isle of Wight, which could not have been carlier than the 19th and was back in London again in time for the child to be christened, with the countess of Surrey as the queen's proxy, on the 22nd, which woald certainly leave him no time to go to Bonthampton to witness tho landing. Seo Ambaesades ds Vxailles, iii. 283. 
suppose that the outwitted diplomatist and supple courtier would do otherwise.

Ill-natured, however, as are Noailles's references to Philip, even they do not, in my opinion, warrant the distorted picture inferentially derived from them. To instance a small matter of which mach is made by Mr. Froude-namely, the vivid scene of the sea-sick prince gulping down beer on the night of his arrival at Southampton, to please the English spectators at his public repast-Noailles says not a word about Philip's being ill or sea-sick, nor do any other chroniclers of the time, that I am aware of. The only foundation for the story seems to be a remark contained in a letter from the earl of Bedford and Lord Fitzwalter from Santiago (' Calendar of State Pepers, Foreign') to the effect that, as the prince suffers much at sea, it will be well to make preparations for him to land at Plymouth, or other port on the south coast if necessary.' The voyage was a beautifully calm one, and the prince laad remained on board the 'Espiritu Santo,' at anchor in Southampton Water, for twenty hours at least before he landed, and, instead of the dramatic scene at his public supper described by $\mathrm{Mr}$. Froude, his repast was a private one and, according even to Noailles, who is alone responsible for the story, after supper, in the presence chamber, Philip told his Spanish courtiers that in fature they nust forget the customs of their country and live like Englisbmen, and 'when, according to the English fashion, a quantity of wine, beer, and ale was brought in silver flagons he took some beer and drank it'-a very simple and appropriate compliment to his new country, but even Noailles tells the story without a hint of the loathing of unwilling sacrifice with which Mr. Froude invests the perfectly natural scene.

Having thus far spoken of the authorities upon which English historians have hitherto based their descriptions of the coming of Philip the Prudent, and pointed out a few of what I venture to think their obvious shortcomings, I will mention some other contemporary narratives which may well, it is true, sin just as much on the score of partiality, but at any rate afford a view of the events recorded that has hitherto been almost entirely ignored-namely, the view taken by those Spaniards who accompanied their prince in his voyage to England in quest of his eager but elderly bride. ${ }^{7}$

Amongst the five nundred courtiers and servants, besides soldiers, who accompanied Philip to England, several would naturally

'Mr. Prescott is the only historian writing in the English' language who referg to Spanish accounts at all, and his reference is confined to a single mention of Cabrera's bald and stolid history and one or two quotations from Sepulveda, who appears to have dorived what little information he gives from one of the narratives now before me. Simon Renard's letters to the emperor in the Granvelle papers are naturally also referred to by most historians of the period in question, but, jmportant as they are from many points of vier, they only give a porely official and diplomatic account, and are Flemiah and imperial rather than Bpanish and personal in their interest. 
be able and disposed to put upon record, for transmission to their friends in Spain, full narratives of the great events they witnessedevents, be it said, which had deeply stirred the public imagination of Spaniards who had been tanght to believe that the marriage of their prince in England would mean not only the mastery of their country over France, bat the restoration of all Christendom to the true faith. These letters, in a period when newspapers were not, would frequently be printed and circulated by enterprising booksellers, and no doubt many of such news letters, both in print and manuscript, are still hidden in bundles and volumes of miscellaneous papers in the public and private libraries in the peninsula. One curious manuscript letter, written from Winchester by Juan de Barahona to Antonio de Barahona, was found in the library of the Escorial fifty years ago, and published in the first volume of the 'Documentos inéditos para la Historia de España' in 1842. The manuscript had belonged to the contemporary chronicler Florian de Ocampo, and gives an extremely full account of the voyage, reception, and marriage, abounding in curious details of the life, dress, and manners of the time. In referring to this narrative in the following pages I shall distinguish it as narrative No. 1.

Many years later there was discovered in the Biblioteca Nacional a record which, to Spaniards at least, was much more raluable and interesting. It was a printed tract entitled

Summary and Veracious Relation of the Happy Voyage made by the Unconquered Prince of the Spains, Don Felipe, to England, and his Reception in Vincester, where he was married, with his Departure for London; in which are contained the great and marvellous things that happened at that time. Dedicated to the Most Mlustrious Lady Donna Laisa Enriquez de Giron, Countess of Bensvente, by Andres Muñoz, Servant to his Serene Highness the Infante Don Carlos. Imprinted in Çaragoça, in the house of Esteban de Najera, 1554, at the cost of Miguel de Çapila, bookseller.

The author was a lacquey to the unhappy Don Carlos, then a child, and his own personal observation is confined to the elaborate preparations for Philip's voyage made in the city of Valladolid and the journey of the little prince to Benavente, in Castile, to take leave of his father. What he saw and heard he relates with a trivial minuteness of detail, particularly as to the persons who were to accompany Philip and the clothes they took with them, which to an ordinary reader would be tedions in the extreme. But although bis own share in the voyage ended at Benavente, whence Don Carlos roturned to Valladolid, Muñoz apparently made arrangements with some member of the suite-no doubt of similar rank to himself-to send him particulars from England, and his account is therefore carried down to the departure of Philip and Mary for London after their marriage. This is by far the fallest account known, especially as to the events prior to Philip's embarkation; but the writer's 
position naturally caused him to dwell mainly upon the sartorial aspect of things which came under his observation, and he describes the splendour and pageantry rather as a spectator than as an actor. I shall call Muñoz's narrative No. 2.

About the same time as the discovery of Munoz's letter three other letters, which in my opinion are even more valuable, because of the position of the supposed author, were found in the Escorial library. The first is a printed tract in the form of a diary and is entitled

Tranecript of a Letter sent from England to this City of Seville, in which is given a Relation of the Events of the Voyage of our Lord the Prince Don Philip, from his Embarkation in the Coruña, a Port of Spain, to his Marriage to the Serene Queen of England. 1554.

The book bears the well-known device, although not the name, of the celebrated Sevillien printer Andres de Burgos. In the same library was found a manuscript letter taking up the narrative where the last-mentioned tract ended-namely, after the marriage at Winchester at the end of July-and carrying it to 19 Augast, when the court was at Richmond. No printed copy of this continuation is known to exist, but it is almost certainly written by the same hand, and contains many remarks and opinions which would probably have been suppressed if the letter had been published. A continuation of this, again, was also found in the Escorial, written apparently by the same person, bringing the narrative down to 2 Oct., and is dated from London, where the king and queen then were. These three letters, which I shall distinguish by the numbers 3, 4, and 5, were published, together with Muñoz's narrative (No. 2), by the Society of Bibliophilists of Madrid in 1877, under the editorship of Don Pascual de Gayangos.

In inquiring into the probable authorship of these three extremely valuable and interesting lettere Señor de Gayangos gives good reason for supposing that they were written by a young courtier named Pedro Enriquez, one of Philip's stewards. He is known to have had a perfect mania for writing relations of what he saw and heard, and has been called the Spanish Tacitus. ${ }^{8}$ He was a brother of the marquis of Villanueva and a relative both of the duke and the duchess of Alba, of whose movements he gives a very minute account in the above letters. He also identifies himself as a steward of the king in one of his complaints of the exclusive service of Philip by Englishmen, nnd is known to bave been one of the very few Spanish noblemen who remained with Philip in London. His style, moreover, is peculiar, and I have had a former opportunity of commenting upon it in connexion with a rapid and industrious piece of historical transcription of his, executed in the follow-

- Cabrera, Relaciones, and Nicolas Antonio, Biblioteca roca. 
ing year in Ghent ; ${ }^{\circ}$ and $I$ have no doubt that Don Pedro Enriquez was the author of the three letters I am speaking of. Fer people could have had better opportunities of observation than he. He accompanied Philip everywhere : his rank and his relationship to the all-powerful Alba brought him within the inner circle of the court, and the feelings he expresses are those of the nobles who surrounded the king and not the gossip of the servants' hall or a valet's list of his master's finery. With these four letters the Society of Bibliophilists printed another by a different author, addressed from London at the end of December 1554, giving a very full account of the reception of Cardinal Pole; but, as this does not touch the subject in hand, I omit any further reference to it.

In the British Museum there is a small tract in Italian, apparently printed in Milan in 1554, called

The Departure of the Serene Prince with the Spanish Fleet, and his Arrival in England, with the Order observed by the Queen in his Highness's Reception, and the most Happy Wedding ; with the Names of the English, Spanish, and other Lords and Gentlemen who were present, and the Liveries, Festivities, and other Things done at the Wedding.

It is signed 'Giovanni Paulo Car,' and the writer was a servant of the marquis of Pescara. A paraphrase or adaptation of the letter also exists in the museum, and appears to have been published in Rome in the same year, but it is not signed and contains many additional particulars. The contents of these two tracts, again, appear to have been blended into a narrative published in the following year, probably in Rome, in which the person to whom the letter is addressed is described as the 'illustrious Signor Francesco Taverna Cracanz,' and although it is not signed by Car it evidently is by him, as he speaks of the marquis of Pescara all through the narrative as his master. I propose in referring to this narrative to call it No. 6. We have thas a mass of contemporary evidence from persons who were certainly attached to Philip's suite, by the aid of which and the authorities already known a more minute and trustworthy account than any hitherto presented of the events in question may be constrncted.

Renard had first broached the sabject of the marriage to Mary in August 1553, and all the attempts of Noailles to inspire fear and hatred of the match in the breasts of the queen and her people had only made her more determined to carry out the wishes of her heart, and, as she no doubt herself thought, to enhance the happiness and prosperity of her people. Egmont and his glittering train had been snowballed by the London 'prentices when he came formally to offer Philip's hand to the queen in January 1554. A whirlwind of passion and panic had passed over southern England

د Chronicle of King Henry VIII of England. London: Bell and Sons. 1889. 
at the thought of a Spanish consort raling in the land, and at about the time that gallant Wyatt and his dwindling troop of 'draggletayles' were wearily toiling up Fleet Street, only to find that the queen's courage and their leader's irresolntion had wrecked their enterprise, a dusty courier clattered into Valladolid with the premature news that Lord Privy Beal, the earl of Bedford, and another English lord had started for Spain with the contract that was to make Philip king of England. His highness was honting at umbrageous Aranjuez, a hundred miles off, and the messenger, just alighting to kiss the hand of poor lame little Prince Carlos, went scouring over the tawny plains again, bearing his pregnant tidings. The courting hed all been done by the emperor through clever Benard, and the prince, dutiful son as he was, bent to his father's will without even knowing the terms of the bargain by which he was to be bound for life. The conditions imposed by the patriotism of Mary and her council were hard for the most powerful monarch on earth to brook for his son. Philip's power was so fenced round by limitations and safeguards that it Was plain to see the English nobles meant his sceptre to be a shadowy one, and the sombre, sensitive pride of the prince was wounded to the quick at the light esteem in which they seemed to hold him; but, as Sandoval says, 'he, like a second Iraac, was ready to sacrifice himself to his father's will and the good of the church.' And he did so gracefully and with dignity. No sooner had the courier delivered his message at Aranjuez than Philip set off on his return to Valladolid with bis gaudy escort of horsemen in their red and yellow doublets. In hot haste the old Castilian capital put on its holiday garb to celebrate the event; the great square, standing much as it stands to-day, was bravely adorned, and costly hangings covered all one side of it where the prince sat to see the jousts, tourneys, cane-play, and fireworks, and where he sat, alas! the next time he saw Valladolid on his return five years afterwards to watch unmoved the hellish fireworks of the great auto de fe.

The wedding rejoicings had hardly begun when they were changed to mourning by the news of the death of Don Juan of Portugal, the husband of Philip's sister Juana, and the narrator Muñoz breaks off in the midst of his rapture over the splendour of Velladolid's joy to relate the pompous grandeur of its sorrowhow between the screen and the altar of St. Paul's there were three thousand candles of white and yellow wax, and how all the solemnity of previous exequies paled before these. In the meantime Philip had sent one of his stewards, Don Gutierre Lope de Padilla, to receive the English enroys at Laredo. After waiting there for a month with the prince's guard to pay them due honour he found that the news sent had been prematare and that the marriage treaty had not yet oven been ratified, and was not, indeed, 
until Egmont's second visit to England in March. So Padilla found his way back again to Valladolid by the end of March, and they decided to take the matter in more leisurely fashion in future. But in a few weeks came news from the emperor himself that the contract was ratified, and then the marquis de las Navas was ordered to take the prince's first present to his bride. We are told that the marquis fitted himself out for his mission regardless of cost, and his splendour appears to have been equalled by the princely gifts of which he was the bearer and the noble hospitality extended to him in England. ${ }^{10}$ Philip's offering to Mary consisted of a great table dismond, mounted as a rose in a superb gold setting, valued at 50,000 ducats; a collar or necklace of 18 brilliants, exquisitely worked and sot with dainty grace, valued at 82,000 ducats; a great diamond with a fine large pearl pendant from it [this was Mary's favourite jewel, and may be seen on her breast in most portraite]. They were [8ays narrative No. 2] the most lovely pair of gems ever seen in the world, and were worth 25,000 dacats.

Then comes a list of pearls, diamonds, emeralds, and rabies of inestimable value and other presents without number for the queen and her ladies. Eighty fine horses and fifty hackneys were sent on to Corñia to await the prince's coming, and all Castile and Aragon, not to speak of Leon, were alive with artificers of the gorgeons garb and trappings to fit out the proad nobles who were to follow their prince, each, with true Spanish ostentation, bent upon outstripping the others in the richness and splendour of themselves and their train. ${ }^{11} \mathrm{Munoz}$, in narrative No. 2, gives a list of the clothes made for each of the principal grandees, which it would be tedious and unnecessary to repeat here.

The prince, great as he was, was only first among his peers, and if he could be magnificent so conld his train, and Alba and Medina-Celi, Egmont and Aguilar, Pescara and Feria vied with their master in their finery. Each great noble-and there were twenty of them-took his train of servants in new liveries, and the prince had a Spanish guard of a hundred gentlemen in red and yellow, a hundred Germans in the same uniform, but with silk facings, ' as their custom is to go bravely dressed,' a hundred archers on horseback, and three hundred servants in the same gaudy colours of Aragon. All this splendid apparatus was a comparatively new thing for Spaniards at the time; the homely, unceremonious relations between sovereign and people hed only been put aside for the pompous etiquette of the house of Burgundy on the coming of

10 Bee letter from Lord Edmand Dadley to the conncil, quoted in Tytler, Eduard VI and sary.

"This was in despite of Renard's recommendation to Philip: Sectement sera requis que les Espaignoles qui suyvront vastre Altere comportent les fafons de faire des Angloys at soient modestes, conflans que oostro Altoss les aicarassera parson humanite cas. tumidre. 
Philip's grandfather from Flanders with his Spanish bride to take up the sceptre dropped by the dead hand of Isabel the Catholic, and the gold of the Indies had since that time poured into Spain and spread a thirst for showy pomp even amongst the frank, honest, homely gentlemen who had formed a majority of the Spanish hidalgo class. The changed taste, however, was new enough still to attract the attention of the crowd, who had not yet become accustomed to so much splendour.

All these elaborate preparations being completed, Philip, with nearly a thousand horsemen, glittering and flashing in the pitiless Castilian sun, left Valladolid on 14 May - not for England yet, but far down on the Portuguese frontier, at Alcantara, to meet his widowed sister, who had been forced to come out of her bitter grief to govern her father's kingdom during Philip's absence. He accompanied her five days on her journey to Valladolid, and then turning aside to take a last leave of his mad grandmother Juana la Loca, bent his course towards Benavente, on the high road to Sentiago, arriving there on 3 June, covered with dust of travel, but gracious, as he could be, to those who had entertained his boy, Carlos, who had preceded him. Next day there was a grand bull fight in the plaza, which Philip and Carlos saw from Pero Hernandez's flower-decked house. The return of the princes to Count Benavente's castle was not quite so dignified as it might have been, as one bull was so 'devilish' that it refused to be killed and held the plaza victoriously against all comers until the next morning, whereupon Philip and his son had to slip out by Pero Hernandez's back door and reach the castle by a roundabout way. The next day there was a hunt and a tourney, and then after supper the princes mounted on a high scaffold, richly dight, to see 'a procession of berutiful and strange inventions.' Torches blazed all round them, and each device was led by one of the neighbouring squires with twenty pikemen and drummers and fifers, each detachment in a separate livery. Elephants manufactured out of horses and pasteboard, castles with savages inside, a green tabernacle with a lovely maiden borne by savages, a model of a ship dressed with English and Spanish flags, and, strangest of all, a girl in a coffin complaining of Cupid, who came behind on horseback. When the device reached the middle of the plaza the god of lore was suddenly hoisted on high by a rope round his middle, and let off fireworks, to the delectation of the crowd. As a relief to this foolery the great Lope de Rueda then represented 'a sacred play with comic interludes,' which no doubt was better worth seeing than the 'conccits and fireworks' that pleased the narrator so much. The next day, after bidding good-bye to the son who was afterwards to hate him so bitterly, the prince started in the cool of the summer night on his way to the sea. At Astorga a splendid reception had been prepared for him, but he 
could not stry and pushed on with all possible speed, news having reached him that the earl of Bedford and Lord Fitzwalter were already awaiting him at Santiago. There he arrived on the vigil of St. John, 23 June, and there as usual golden keys were offered by kneeling citizens; silks and satins, velvets and brocades flaunted in the sun, and in the upper vindow of a house on the line of roate sat the two English lords, their mantles before their faces, watching the progress of their future king to worship at the shrine of the Spanish patron saint, St. James. The next morning Philip sent a party of his highest nobles to bring Bedford and Fitzwalter to him, and

being advised of their coming, his highness came out of his chamber into a great hall, strangely hung with rich tapestries, and on the lords half kneeling and doffing their bonnets the prince received them graciously with his hat in his hand. The principal ambassador, a grandeo and a good Christian, produced the marriage contract, the conditions of which his highness accepted before all present. As the contents were only known to the prince and his council, we were unable to learn them. The English nobles then kissed hands in turn, and as they went out one said to the other in his own tongue, 'Oh! God be praised for sending us so good a king as this !' The remark was made so quietly that it would not have been noticed only that a Spanish gentleman who understood their language stood close to them and happened to hear it.

The envoys had some reason to be pleased with their queen's future consort, for after accompanying him to the cathedral the next day Bedford received as a gift what is described as being one of the finest pieces of gold ever seen, of exquisite and elaborate workmanship, chased with grotesque figures, and standing a yard and a half high, of solid gold. The narrator (No. 2) says that 6,000 ducats' worth of gold was employed in the making of it, and the handiwork cost more then a thousand. The twenty English gentlemen who accompanied the enroys all received splendid gifts, although their appearance was already sufficiently rich with their 'thick gold chains and great copiousness of buttons,' which last characteristic of Finglish fashion of the time seems to have attracted most of the Spanish observers. Four days were spent in rest and rejoicing at Santiago, and then a three-days' ride brought them to Coraña, where there were more rejoicings. Kneeling aldermen at the gate presented golden keys, as usual; a marvellous canopy was held over the prince's head; triumphal arches spanned the way; and the local poet had contrived to evolve the following couplet, which was held aloft by five nymphs :

No basta fuerza ni maña Contra el principe de España]

which may be rendered- 
Force and cunning both in vain

Strive against the prince of Spain.

The narrator (No. 2) airs his historical knowledge in describing an allegorical group containing a figure of Hercules, whom he speaks of as having been

a king of Spain before Christ, and having built many great edifices in the country, such as the Pillars of Hercules at Cadiz and the tower at the entrance to the port of Coruña, where there is a marvellous mirror. showing shirs that are far off at sea.

With all pomp, and with a naked sword of justice borne before him by his master of the horse, the prince was conducted to the shore to see the gallant fleet riding at anchor awaiting him. Drawn up on the beach were 600 Guipuzcoan sea warriors, armed with lances, and as the fleet and castle thundererl out their salutations the townsfolk, we are told, feared their dwellings would all be shaken down, and ' for an hour and a half neither heaven nor earth was visible.' Thence the prince went round by the castle to the little dock, where forty Biscay fisher boats were ready with their glistening cargoes of fine fish to cast at the feet of their beloved Philip. The English ambassadors begged as a favour that the new consort would make the voyage in one of the British ships that had brought them over, but this was not considered prudent by Philip's cautious councillors, and as a compromise the English envoys were allowed to choose from amongst all the Spanish ships the one that was to convey the prince. Their choice fell upon a fine merchant vessel commanded by the bravest and best of those bold Biscay mariners who are the pride of Spain, Martin de Bertondona, and the next morning Philip and his court sent to inspect it. A splendid sight it must have been with its torvering carved and gilded poop and forecastle. It was hung, we are told, from stem to stern with fine scarlet cloth, and aloft on every available spot were coloured silk pennons. The forecastle was hung with crimson brocade painted with golden flames. A royal standard thirty yards long, of crimson damesk with the prince's arms painted on it, hung from the mainmast, and a similar flag from the mizzen-mast. The foremost had ten pointed silk flags painted with the royal arms, and there were thirty other similar flags on the stays and shrouds. Three hundred sailors in red uniforms formed the crew, and we are assured that the effect of the ship was that of a lovely flower garden, as well it might be, and the cost of the decorations was ten thousand ducats. The English ships were then inspected and admired, and the ship that had carried the marquis de las Navas over to England with the jewels was visited, and its captain told how the good queen was anxious for her corsort's arrival, and how she had ordered a thousand gentlemen to 
await him with as many horses, as she thought no horses would be brought from Spain. All next day is spent in hunting, and the favourite Ruy Gomez, preceding his master on his retarn into the town, is saluted by the fleet insterd of the prince by mistake, much to the latter's amusement. The next day heralds announced that everyone was to be examined by the prince's alcalde before embarking, and that no woman was to go without her husband. Muñoz aays that 12,000 soldiers were shipped in the hundred ships (some of 300 bronze pieces) and thirty sloops that formed the fleet, but this seems to be an exaggeration, as narrative No. 6 gives 6,000 soldiers and as many sailors as going in the main squadron that convoyed Philip (consisting of about a hundred sail), and Noailles, who would minimise it as much as possible, says 4,000. Don Luis de Carvajal remained behind with about thirty sail to take the troops that had not arrived (Noailles says 2,000) and bring up the rear.

On 12 July Philip and his court embarked in a samptuous galley of twenty-four oars, manned by sailors in scarlet and gold with plumed hats of scarlet silk, and, amidst music, singing, and daring gymnastic feats of the mariners, went on board Martin de Bertondona's ship, the 'Espirita Santo.' The next day, Friday, at three in the sfternoon they set sail, the dense crowd on shore crying to God to send the travellers a safe voyage, and in the same breath hurling defiance to the French. There was a slight swell and wind until next day at dinner, when the weather fell dead calm, 'which looked a.s if it might last a month, but raised the spirits of those who were depressed by "marine vomitings." ' The next day a delightful fair breeze sprang up, and on a smooth sea the splendid fleet ran across the bay, sighting Ushant on Sunday. On Wednesday a Flemish fleet of eighteen galleons, which was cruising in the Channel, hove in sight, and convoyed them past the Needles with some ships of the English navy into Southampton Water, where on Tharsday, 19 July, at four o'clock, the combined fleets anchored amid the royal salnte from the English and Flemish fleets of thirty sail that were assembled to receive them. The English and Flemish sailors had not got on particularly well together during the time the two fleets had awaited the arrival of Philip. Renard had complained to the emperor that the Flemish sailors were hustled and insulted whenever they set foot on shore, and Howard, the lord admiral, had mocked at their ships and called them cockle shells, ${ }^{12}$ but I can find no contemporary authority for the extremely onlikely story of the English admiral having thrown a shot across the bows of the prince's fleet to compel it to salute the English flag. But Philip was determined to gain over the jealous hearts of his new subjects by his courtesy and graciousness. Renard's recommendations and the emperor's

12 Renard to the emperor, quoted in Tytler, Edward FI.and Mary. 
instructions had been very definite on the point, and every account, Spanish, English, and Italian, with the sole exception of Baoardo's, quoted by Froude, agrees that the prince's demeanour was kindly, courteous, and frank. Damula, the Venetian ambassador to the emperor, writes to the doge, ${ }^{13}$ saying that on disembarking he treated everybody with great graciousness and affability, without any pomp or royal ceremony, mixing with people as a comrade, and Cabrera, speaking of his arrival, says-

Some of the English were inclined to be sulky, but the king won them over with his prudence and affability, and with gifts and favours, together with his family courtesy. [Our narrative No. 6 specially mentions the prince's cortesia e gentilezza di parlare. $\left.{ }^{14}\right]$

As soon as the anchors were down the English and Flemish admirals went on board to salute the prince, and the marquis de las Navas put off from Southampton with the six young noblemen who were to be the new king's lords-in-waiting (Noailles). The prince dined and slept on board, and the next day there came off to him the emperor's ambassador, the marquis de las Naras, Figueroa (the ancient ambassador with the long white beard), Pescara, and the earls of Arundel, Derby, Shrewsbury, and Pembroke (?). Noailles was probably wrong as regards the last-named nobleman, as the Spanish narratives agree that he arrived at Southampton from the queen next day, with a splendid escort for the new sovereign. He was also wrong in asserting that the king was invested with the garter on board his vessel, for it appears to have been given to him in the barge before he stepped on shore by Arundel, probably assisted by Sir John Williams-Lord Williams of Thame ${ }^{15}$ - to whom one of our narratives says the prince gave the wand of chamberlain, whilst the other narratives any the office was conferred on 'the man who brought him the garter.' The fature consort received these high personages on board the 'Espíritu Santo' cap in hand, and after presenting them to his principal courtiers went on board the splendid barge awaiting him, accompanied by the

1 " 22 Jaly, Calendar of State Papers, Venetion.

14 Soriano, the Venetian ambassador in Madrid, says that the gentle courtesy he adopted in England was continued after his return to Spain, and that whilst maintaining his natural gravity and dignity his kindness and graciousness were remarkable to all persons. Michaeli, the Venetian ambassador in Iondon, who had sided with Nosilles in his opposition to the match, is emphatio in his testimony of Philip's affability whilst in England, and says that his conduct towards his wife was enough to make any woman love him, 'for in truth no one else in the world could have been a better or more loving husbend.' These and many other similar contemporary assurances prove that Philip actod all through the business like an honest, high-minded gentleman.

is He died in 1559, and a magnificent alabaster monument, with the recumbent figares of himself and his wife, exists in fine preservation in the chancel of Thame church, of which he was a liberal benefactor. 
English nobles and by Alba, Feria, Ruy Gomez and four chamberlains, Olivares, Pedro de Cordoba, Gutierre, Lopez de Padilla, Diego de Acevedo, Egmont, Horn, and Bergues. No sign was made to the rest of the fleet, and the mass of courtiers only obtained leave to land after the royal party had approached the shore. No soldier or man-at-arms, however, was to land, on pain of death, for not only had Philip learnt from Renard the agony of distrust of the Spanish arms felt by the English people, but he had received news of his father's reverse in the Netherlands and urgent orders to send him all the troops and money he had or could obtain. The Spanish fleet were not even allowed to enter the port of Southampton, but after some delay, and great discontent of the Spaniards at what they considered such churlish treatment, were sent to Portsmouth to revictual for their voyage to Flanders. After the presentation of the chain and badge of the garter Philip stepped on English soil, and the first to greet him was Sir Anthony Browne, who announced in a Latin speech that the queen had chosen him for her consort's master of the horse, by whom her majesty had sent him the beautifnl white charger housed in crimson velvet and gold that was champing the bit hard by. The prince thanked his new grand equerry, but said he would walk to the house prepared for him ; but Browne and the lords of the household told him this was unusual, and the former ' took him up in his arms and put him on the saddle, and then kissing the stirrups walked bare-headed by the side of his master. All the English and Spanish courtiers preceded them, and amidst apparent rejoicing they slowly passed through the curious crowd to the church of the Holy Rood. The prince must have looked an impressive figure with his erect bearing, his yellow beard and closecropped yellow head, dressed as he was in black velvet and silver, his massive gold chains and priceless gems glittering in his velvet bonnet and at his neck and wrists. Browne was no unworthy pendant to his prince. He was dressed in a suit of black velvet entirely covered with gold embroidery and a surcost of the same with long hanging sleeves. ${ }^{16}$ When the prince had returned thanks for his safe voyage he was conducted to the lodgings prepared for him, which we are told were beautifally adorned, particularly two rooms, a bedroom and presence chamber hung with gold-worked damask with the name of King Henry on it; but none of our narrators say anything about Baoardo's story of the dismay caused by the words Fidei defensor. All the English archers and the guard and porters about the prince wore the flaming colours of Aragon, and the Spanish attendants and courtiers looked on with jealous rage at the clumsy attendance on him of the English servants. The dinner and supper were private, but the meals were

11 Probsbly the dress in which he is represented in the magnificent painting of him belonging to the marquis of Exeter at Burghley (No. 286, Tudor Exbibition). 
ostentatious, ceremonious, and too abundant for the Spanish taste. On Saturday, the next day, the same programme was gone through : to mass in the aame order as before, the Spanish courtiers being obliged to leave before the service was over, in order to banish the idea that they were in official attendance on the prince, who came out surrounded by Englishmen only. It rained so hard that his highness, who had no hat or cape, had to borrow them of an Englishman near him, although the church was just opposite his lodging.

Southampton is described in glowing terms. It is said to be a beautifal port with three hundred houses, which were filled to their atmost capacity by the courtiers and the four hundred Spanish servants who landed the day after the prince. The queen at Winchester had learnt post haste of the landing of her future husband, and an active interchange of messengers was soon scouring backwards and forwards through the pitiless rain of the next three days. Early on Saturday morning the earl of Pembroke arrived from the queen with an escort of two hundred gentlemen dressed in black velvet with gold chains and medals, and three hundred others in scarlet cloth with velvet facings, all splendidly mounted. Then Egmont posts off to kiss the queen's hand, and meets Gardiner coming to Philip with a costly diamond ring from her majesty. The next day twelve beautiful hackneys come from the bride to her affianced husband, and after that the well-beloved Ray Comez is despatched with a ring and to thank her, and this interchange of courtesy and compliment is thus kept up until all things are arranged for the journey to Winchester. Before they left Bouthampton, however, better news came from Flanders. The French had not followed up their rictory at Marienberg, and the imperialists could breathe again. The six hundred jennets that came from Spain were therefore disembarked and remained in England, as well as Philip's own horses, 'which,' says Pedro Enriquez (No. 3), ' the master of the horse took to his own stable; not a bad beginning to try and keep them altogether in the long run.' On Sunday, the day before he left Southampton, Ptilip dined in public for the only time there. He was served with great ceremony by the English, but Alba, although he took no wand of office in his hand, insisted on handing his master the napkin, and the Spanish courtiers looked on with ill-disguised rage at what they considered the clumsy service of their successors. The courtier who wrote narrative No. 8 bursts out at this point with his complaint-

My lady Doña Maria de Mendozs mas quite right when she said we should be no more good. We are all quite vagabonds now and of no use to anyone. We had far better go and serve the emperor in the war. They make as pay trenty times the valne of everything we buy. 
The next morning in the pouring rain the royal cavalcade set out for Winchester 8,000 strong. The nobles and gentry had. been flocking in for days with their retainers in new liveries; Pembroke's escort, with 200 halberdiers of the guard and as many light-horse archers, dressed much as are the beefeaters of to-day, guarded the prince's person, the Spanish guard, to their chagrin, being still on board the ships. On the road 600 more gentlemen, dressed in black velvet with gold chains, met his highness, and when nearing Winchester six of the queen's pages, besutifully dressed in crimson brocade with gold sashes, with as many superb steeds, were encountered, who told his highness the queen had sent the horses to him as a present. But not a word anywhere of Baoardo's sensational story, embellished by Mr. Froude, of the breathless messenger from the queen, the terror-stricken prince, and the gloomy resolve to consummate his sacrifice even if he got wet in doing it.

,Philip was surrounded by the English nobles Winchester, Arundel, Derby, Worcester, Bedford, Rutland, Pembroke, Surrey, Cliniton, Cobham, Willoughby, Darcy, Maltravers, Talbot, Strange, Fitzwalter, and North, and by about fifteen Spanish grandees, whose names will have less interest for English readers. He was dressed, when he started, in a black velvet surcost adorned with diamonds, leather boots, and trunks and doublet of white satin embroidered with gold; but this delicate finery had to be covered by a red felt cloak to protect it from the rain. Notwithstanding this it was too wet for him to enter Winchester without a change, so he stayed at a "hospital that had been a monastery one mile from the city,' and there donned a black velvet surcost covered with gold bugles and a suit of white velvet trimmed in the same way, and thus he entered, passing the usual red-clothed kneeling aldermen with gold keys on cushions, and then to the grand cathedral, which impressed the Spaniards with wonder, and above all to find that 'mass was as Bolemnly sung there as at Toledo.' A little crowd of mitred bishops stood at the great west door, crosses raised and censers swinging, and in solemn procession to the high altar, under a velvet canopy, they led the man whom they looked upon as God's chosen instrument to reatore their faith in England. Then, after admiring the cathedral, Philip and his court went to the dean's house, which had been prepared for his reception, in order to allay the maiden scruples of the queen with regard to his sleeping under the same roof with her at the bishop's palace before the solemnisation of the marriage. After Philip had supped, and presumably was thinking more of going to bed than anything else, the lord chamberlain ${ }^{17}$ and the lord steward ${ }^{18}$ came to him, it being ten o'clock at night, and said the queen was waiting for him in her closet, and wished him to visit her secretly with very fow followers. He at once put on another "Bir John Gage. 18 The earl of Arundel. 
gorgeous suit, consisting of a French surcoat embroidered in silver and gold and a doublet and trunks of white kid embroidered in gold, 'and very gallant he looked,' says Mur̃oz's informant (No. 2). The party traversed a narrow lane between the two gardens, and on reaching a door in the wall the lord steward told the prince he could take with him such courtiers as he chose. Philip did not seem disposed to run any risks, and construed the invitation in a liberal spirit, taking into the garden Alba, Medina-Celi, Pescara, Feria, Aguilar, Chinchon, Horn, Egmont, Lopez, Acevedo, Mendoza, Carillo, and others. They found themselves in a beantiful garden with rippling fountains and arbours, which reminded them, they say, of the books of chivalry. Indeed nothing is more curious than the grave seriousness with which all the Spanish narrators refer to England as the land of Amadis and of Arthur and his knights, and their attempts to identify localities and characteristics of England with the descriptions they have read of the land of romance, which they firmly believe to be England and not Brittany.

The prince and his party entered by a little back door and ascended a narrow winding staircase to the queen's closet. She was in a 'long narrow room or corridor where they divert them. selves,' surrounded by four or five aged nobles and as many old ladies, the bishop of Winchester being also with her, and the whole party, we are told, was marvellously richly dressed, the queen herself wearing a black velvet gown cut high in the English style without any trimming, a petticoat of frosted silver, a wimple of black velvet trimmed with gold, and a girdle and collar of wonderful gems. She was walking up and down when the prince entered, and as soon as ahe saw him went quickly towards him and kissed her hand before taking his. In return he kissed her on the month 'in the English fashion,' and she led him by the hand to a chair placed by the side of her own under a canopy. The queen spoke in French and her future husband in Spanish, and they thus made themselves well understood. Whilst they were in animated converse the lord admiral (Lord William Howard), ' who is a great talker and rery jocose,' risked some rather highly flavoured jokes, which the free manners of the time apparently permitted. The two lovers sat under their brocade canopy chatting for a long time; but this probably seemed somewhat slow to the bridegroom, who, after asking the queen to give her hand for all his Spaniards to kiss, as they loved her well, begged to be allowed to see her ladies, who were in another room. The queen went with him, and as the ladies approached two by two he kissed them all 'in his way' with his plumed cap in his hand, 'so as not to break the custom of the country, which is a very good one.' Whether the queen thought it good on this occasion is not clear; but when her lover wanted to leave directly the extensive osculation was over she would not let him 
go, but carried him off for another long talk with her. ' No wonder,' says the narrator (No. 2), 'she is so glad to get him and to see what a gallant swain he is.' When he had to leave her she playfully taught him to say 'Good night,' and he made this the excuse for going to the ladies again to say it to them; but when he reached them he had forgotten the outlandish words, and hed to come back to the queen to ask her, 'whereat she was much pleased,' but probably less so when he found it necessary to go back once more to the ladies to salute them with 'God ni hit.' Car, the marquis of Pescara'e servant (narrator No. 6), in describing this interview says that the queen's governess told the prince she thanked God for letting her live to see the day, but asked his pardon for not having reared a more beautiful bride for him. According to one of the Italian variants of the same narrative the queen is still less complimentary to herself, and in reply to Philip's thanks to her after the marriage says it is she who is grateful to him for taking an old and ugly wife ${ }^{10}$ (britta c vecchia). The courtier's narrative (No. 4) speaks of the queen in somewhat less unfavourable terms and says-

Although she is not at all handsome, being of short stature and rather thin than fat, she has a very clear red and white complexion. She has no eyebrows, is a perfect saint, but dresses very badly.

This narrator is very critical about the ladies' dresses and is quite shocked at some of the English fashions. He says-

They wear farthingales of coloured cloth without silk; the gowns, they wear over them are of damask, satin, or velvet of various colours, but very badly made. Some of them have velvet shoes slashed like men's, and some wear leather. Their stockings are black, and they show their legs even up to the knees, at least when they are travelling, as their skirts are so short. They really look quite indelicate when they are sented or riding. They are not at all handsome, nor do they dance gracefully, as all their dancing only consists of ambling and trotting. Not a single Spanish gentleman is in love with any of them ${ }^{20} \ldots$ and they are not women for whom the Spaniards need put themselves out of the way in entertaining or spending money on them, which is a good thing for the Spaniards.

When the same narrator reaches London he speaks with somewhat more experience, but his opinion is not much modified. He says, when speaking of the vast numbers of ladies that served the queen-

Those I have seen in the palace have not struck me as being handsome; indeed, they are downright agly. I do not know how this is,

1) In the narrative signed by Car (British Musenm) the queen is desoribed in this interview as 'chatting gaily, and although she is a little elderly she displays the grace befitting a queen.'

to Don Pedro Enriquez pas wrong here. One of the greatest of the Spanish nobles, count de Feria, had fallen madly in love with Catharine Dormer, one of the queen's maids of honour, and soon atterwards pritately married her. 
because outside I have seen some very beantiful and attractive women. In this country women do not often wear clogs and wraps, as they do in Spain, but go about the city and even travel in their bodices. Some of them walk in London with veils and mosks before their faces, which makes them look like nuns, who do not wish to be known. Women here wear their skirts very short, and their black stockings are trim and tightly gartered; the shoes are neat, but are slashed like men's, which does not look well to Spanish eyes.

Philip, we are told, slept late next morning, and as soon as he was up the queen's tailor brought him two superb dresses, one made of very rich brocade profusely embroidered with gold bugles and pearls, with splendid diamonds for buttons, and the other of crimson brocade. His highness went to mass in a purple velvet surcost with silver fringe and white satin doublet, and then after his private dinner went in great state to see the queen. She received him in the great hall of the palace, with the courtiers ranged on a raised platform on each side. The great officers of state preceded her, and she was followed by fifty ladies splendidly dressed in purple velret, ' but none of them pretty,' and having met her consort in the middle of the hall she led him to the dais, where he stood in sweet converse with her for some time. But fickle Philip 'went, as usual, to talk to the ladies, and re, about twelve of us, kissed the queen's hand.' 'We' also seem to have been talking to the ladies before that, but do not appenr to have got on very well, as ' re could hardly understand each other.' Then Philip went to vespers and the queen to her chapel, and after supper they met again, and Figueroa privately read the emperor's abdication, which made Philip king of Naples, and all the ambessadors except Noailles paid homage to the new sovereign, who received them bare-headed. ${ }^{\text {n }}$

The wedding ceremony next day is fully described by the English authorities already mentioned, and the narratives before us, although extremely minute in detail, do not vary much from the accepted accounts. The ancient cathedral was all aflame with splendid colour, and the world has rarely seen so gorgeous and so rich a company as was there assembled. All the pomp that regal expenditure could buy in an age of ostentation was there. All the impressive solemnity that the Roman church could give to its ceremonies was lavished upon this. The queen, we are told, blazed with jewels to such an extent that the eye was blinded as it looked upon her; her dress was of black velvet flashing with gems, and a splendid mantle of cloth of gold fell from her shoulders; but through the mass that followed the marriage service she never took her eyes off the crucifix upon which they were devoutly fixed. Her fifty ledies

21 Baoardo, quoted by Mr. Froude, says 'he raised his hat to nobody,' but these narratives often mention his being unoovered. 
were dressed in cloth of gold and silver, and 'looked more like celestial angels than mortal creatures.' Philip matched his bride in splendour. He too wore a mantle of cloth of gold embroidered with precious stones, and the rest of his dress was the white satin Buit the queen had sent him the day before, and he too was a blaze of jewels. The earl of Derby, who preceded the queen with a sword of state, appears to have greatly impressed the imaginations of the Spaniards, as several references are made to his power and splendour. He is spoken of as the ' king of Mongara (Man), who wears a leaden crown,' and it is easy to see that much of the interest in him is caused by the supposed identification of his kingdom with scenes of the romances of chivalry.

After the ceremony the king and the queon walked through an immense crowd to the palace side by side, and entered the great hall, ${ }^{28}$ which the narrator (No. 2) calls the 'hall of Poncia,' for the wedding banquet. A high table eight yarda long was placed on a dais, and at it sat the king and queen, the latter being on the right and in a finer chair than her husband. Gardiner sat at the end of the high trble, and on the floor were four other tables, where the nobles to the number of 158 partook of the feast. Before the king and queen stood Lords Pembroke and Strange with the sword and staff of state, and all the stately ceremony of saluting the dishes as they are brought in and doffing bonnets to the throne even in the absence of the queen is set forth with admiring iteration by the form-loving Spaniards. Their jealous eyes too do not fail to notice that the queen takes precedence in everything. Not only has she the best chair, but she eats from gold plate, whilst her consort eats from silver. This, they say, is no doubt because he is not yet a crowned king, and it will be altered later. All the tables are served with silver, except some large dishes; and great sideboarda of plate stand at each end of the hall. The buffet behind the high table had over a hundred great pieces of gold and silver plate, with a 'great gilt clock half as high as a man' and a fountain of precious marble with a gold rim. There were four services of meat and fish, each service consisting of thirty dishes, ${ }^{20}$ and

27 Narrator No. 6 says, ' The hall, which is besutifully hang with cloth of gold and silk, measures forty of my paces long and twenty wide.'

- Underhyll (Harleian Manuscript, 425, f. 97) gives a very quaint account of his 3hare in this banquet. 'On the maryege daye the kynge and quene dyned in the balle in the bushop's palice eittynge under the cloth of estate and none eles att that table. The nobillitie satte att the syde tables. Wee [i.e. the gentlemen pensioners] Feare the cheffe sarueters to cary the meate and the yearle of Bassex ower captayne was the shewer. The seconde course att the maryage off a kynge is geryne anto the bearers; I meane the meate butt nott the disshes for they weare off golde. It was my channce to carye a greate pastie of a redde dere in a greate charger uery delicately baked; which for the weyght thereoff dyuers refused; the wyche pastie I rentt anto London to my wyfle and her brother who cherede therewith many of ther frends. I ryll not take uppon me to wryto the maner of the maryage, off the feaste nor off 
minstrels played during the feast, whilst the solid splendour and pompous ceremony appear to have impressed all the Spaniards with wonder not unmixed with envy. It is indeed here that the jealousy of the courtier narrator (Nos. 3, 4, and 5) first bursts out. The only Spaniard who was allowed to serve the king was Don Inigo de Mendoza, son of the duke of Infantado, who was cupbearer, and four yeomen of the mouth, who helped, but

as for any of the prince's own stewards doing anything, such a thing was never thought of, and not one of us took a wand in our hands, nor does it seem likely we ever shall, neither the controller nor any one else, and they had better turn us all out as vagabonds.

The earl of Arundel presented the ewer with water for the king's hands and the marquis of Winchester the napkin. The ewer, we are told (nerratice No. 6), contained ' not water but white wine, as is the custom here.'

Then, after the queen had pledged all her guests in a cup of wine and a herald had proclaimed the titles of Philip as king of England, France, Naples, and Jerusalem, prince of Spain, and count of Flanders, the royal party retired to another chamber with the English and Spanish nobles, where the time passed in pleasant converse, the Spaniards talking with the English ladies,

although we had great trouble to make out their meaning, except of those who spoke Latin, so we have all resolved not to give them any presents of gloves until we can understand them. The gentlemen who speak the language are mostly very glad to find that the Spaniards cannot do so.

When all was ready the ball began, but as the English ladies only danced in their own frshion and the Spanish courtiers in theirs the latter were rather left out in the cold until the king and queen danced a measure together in the German style, which was known to both. After dancing until nightfall supper was served with the same ceremony as dinner, and then more talk and gallant compliment, and so to bed.

The next day the king alone was visible, and dined alone in public, and on the succeeding day the same; but on the third day (Saturday) the queen heard mass in her private pew and receired the duchess of Alba, who had arrived from Southampton after the marriage. The reception of this proud dame was ceremonious enough for anything, but from the bitter complaints of her kinsman, who probably wrote three of the letters before $\mathrm{us}$, it is clear that she, in common with the rest of the Spanish nobles, was deeply

the dannsayngs of the Spanyards thatt day who weare greatly owte off countenaunce specyally King Phelip dauncynge when they dide see me lorde Braye, Mr Carowe and others so farre excede them; but wyll leve it unto the learned as it behovithe hym to be thett shall wryte a story off so greate a tryoumffe.' The Louvain chronicle (Tytler) says: 'The dinner lasted till six in the orening, after phich there Fas store of music, and before nine all had retired.' 
dissatisfied with her position in this country, so different from what they expected. The duchess was conducted to the palace by the earls of Kildare and Pembroke and all the court, and when she entered the presence the queen came almost to the door to meet her. The duchess knelt, and the queen failing to raise her courtesied almost as low and kissed her on the month, 'which she usually does only to certain ladies of her own family.' She led the duchess to the dais and seated herself on the floor, inviting her guest to do likewise, but the latter begged her majesty to sit on the chair before she (the duchess) would sit on the floor. The queen refused to do so and sent for two stools, upon one of which she sat, whereupon the duchess, insteed of accepting the other, sat beside it on the floor. The queen then left her stool and took her place on the floor also, and finally after much friendly wrangling both ladies settled on their respective stools side by side. The queen understood Spanish but spoke in French, and the marquis de las Navas interpreted to the duchess, who only onderstood Spanish. When the earl of Derby was presented to the duchess he greatly shocked her by offering to kiss her on the mouth, according to the universal English fashion, and she drew back to avoid the salute, bat not quite in time, although she assured the Spaniards that the earl had only managed to kiss her cheek. But the chagrin of the prond, dissatiefied Spaniards was growing deeper as they saw their hopes of domination in England disappear. The men-at-arms and body guard, cooped up in their ships at Portsmouth and Southampton, forbidden to land under pain of death, were becoming restive; the courtiers and their followers, scoffed at and insulted in the streets and waylaid and robbed if they ventured into the country, were forced to put ap with everything silently, by order of the king, but they could relieve their minds by writing to their friends in Spain an account of their sorrows. Writing from Winchester, narrator No. 2 says-

After all this weary voyage these people wish to subject us to a certain extent to their laws, because it is a new thing for them to have Spaniards in their country, and they want to feel safe. The Spaniards here are not comfortable, nor are they so well off as in Castile. Some even say they would rather be in the worst stubble field in the kingdom of Toledo than in the groves of Amadis.

The courtier who wrote No. 8 is even more emphatic. He says-

Great rogues infest the roads and have robbed some of our people, amongst others the chamberlain of Don Juan de Pacheco, from whom they took 400 crowns and all his plate and jewelry. Not a trace has been found of them, nor of the four or five boxes missing from the king's lodgings, although the council is sending out on all sides. The friars have had to be lodged in the college for safety and bitterly repent having come. 
But dissatisfied as the Bpaniards were there was still sufficient novelty in their surroundings during their stay at Winchester in the last days of July to keep them amused. The wonderful round table of King Arthur in the castle where the twelve peers are still enchanted, and their names written round in the places where they eat, claims the wondering attention of the visitors. The curions beer made with barley and a herb, instead of wheat as in Flanders, is discuesed, and the strange habit the ladies-and even some gentlemen-have of putting sugar in their wine and the never-ending dancing going on amongst the ladies of the palace excite remark. On the last day of July most of the lords and squires had gone home for the present; the Spaniards were distributed about Winchester and Southampton; the admiral of Spain was under orders to take a part of the fleet back again, and the bulk of the Spanish troops were only awaiting a fair wind to take them to Flanders, and the king and queen with a small suite set out for Basing, the lord treasurer's " house, fifteen miles off. Most of the accounts before us end at this point, but the two interesting letters to which I hove given the numbers 4 and 5 , written respectively from Richmond and London, show clearly the gradual exacerbation of the dislike between the Spanish and English as time went on, in spite of the diplomatic attempts to connect Philip's name at every opportanity with acts of clemency and moderation.

On 19 August, which is the date of the letter from Richmond, the royal honeymoon seems not entirely to have waned.

Their majesties are the happiest couple in the world, and are more in love with each other than I can say here. He never leaves her, and on the rosd is always by her side, lifting her into the saddle and helping her to digmount. He dines with her pablicly sometimes, and they go to mass together on feast days.

This letter from Richmond gives the following curious account of the lavish scale on which the royal establishment was maintained :-

All the rejoioings here consist only of eating and drinking, as they understand nothing else. The queen spends 800,000 ducats [e year?] in food, and all the thirteen councillors and the court favourites live in the palace, besides the lord steward, the lord chamberlain, the chancellor, and our people with their servants. The ladies also bave private rooms in the palace, with all their servants, and the queen's guard of 200 men are also lodged there. Each of the lords has a separate cook in the queen's kitchens, and as there are eighteen different kitchens such is the hurlyburly that they are perfect hell. Although the palaces aro so large that the smallest of the four we have seen is infinitely larger, and certainly better, than the Alcazar of Madrid, they are still hardly large enough to

I This was the marquis of Winchester, not, as Seffor Chyangos sapposes, Sir Edward Peokham, who was treacurer of the Mint. 
hold the people who live in them. The ordinary [daily ?] consumption of the palace is 100 sheep (which are very large and fat), twelve large oxen, eighteen calves, besides game, poultry, venison, wild boar, and a great number of rabbits. Of beer there is no end, and they drink as much 88 would fill the river at Valladolid.

The writer is very indignant at the scant courtesy paid to his great kinsfolk the Albas, and at the fact that they have had to put up with lodgings that are considered below their dignity even in the villages.

It is not enough [he says] to deprive them of their office, but they must needs give them bad quarters as well. . . These English are the most ungrateful people in the world, and hate the Spaniards worse than the devil, as they readily show, for they rob us in the town itself, and not a soul dares to rentare two miles on the rosd without being robbed. There is no justice for us. We are ordered by the king to avoid disputes and put up with everything whilst we are here, enduring all their attacks in silence. They therefore despise us and treat us badly. We have complained to Bibriesce and the ambassador, bat they say it is for his majesty's sake that we must bear everything patiently.

It was no wonder that under such circumstances these proud hidalgos begged to be allowed to join the emperor in Flanders for the war. Medina-Celi was the first to revolt at his treatment, and no sooner had he obtained leave to go than eighty other gentlemen followed him with their suites, and so by the middle of August the only Spanish nobles in attendance on Philip were Alba, Feria, Olivares, Pedro de Cordoba, Diego de Cordoba, and three gentlemen, amongst whom was Pedro Enriquez, the supposed author of the letters. The insults upon the Spaniards personally were bad enough, but what was more galling even was the disappointment they felt at the political effect of the match. Instead of a submissive people, ready to bow the neck at once to the new king and his followers, they found a country where even the native sovereign's power was strictly circumscribed, and where the foreigner's only hope of domination was by force of arms; and this they saw in the present case was impossible. Enriquez (if he be the anthor) says-

The marriage will indeed have been a failare if the queen have no children. They told us in Castile that if his highness became king of England we should be masters of France; but quite the contrary has tarned out to be the fact, for the French are stronger than ever and are doing as they like in Flanders. . . . Kings here have as little power as if they were vassals, and the people who really govern are the councillors; they are not only lords of the land, but lords of the kings as well. They are all peers, some of them raised up by the church revenues they have taken and others by thcir patrimonial estates, and they are feared mucb more than the sovereign. They publicly say they will not let the ling $\varepsilon c$ until they and the queen think fit, as this country is quite big enough for any one king. 
Great preparations were made for the entrance of the queen and her consort into London. The signs of vengeance had been cleared away, and the city was as bright and gay as paint and gilding could make it. The 'galluses' from which dangled the fifty dead bodies of the London trainbandsmen who had deserted to Wyatt at Rochester Bridge were cleared away from the doors of the houses in which their families lived, and the grinning skulls of the higher offenders were taken from the gates and from London Bridge; but London, for all its seeming welcome and for all its real loyalty to the queen herself, was more deeply resentful of the Spanish intrusion than any city in the realn, and the fow Spaniards who still remained with Philip repaid with interest the detestation of the Londoners towards them.

We enter London [uarrative No. 4] on Saturday next, but, considering their treatment of the Spaniards already there, we onght to atay away. Not only will they give them no lodgings, ${ }^{23}$ but they $\varepsilon$ ffront them on every opportunity, as if they were barbarians, malireating them and robbing them in the taverns to their hearts' content. The friars brought by his majesty had better not have $\operatorname{come}$, for these English are so godless and treat them so vilely that they dare not appear in the streets.

Only a few days before this letter was written from Richmond (19 Aug.) two Spanish noblemen of the highest rank, Don Pedro and Don Antonio de Cordoba, ventured to walk in the streets of London in their habits as knights of Sentiago, with the great crimson cross embroidered on their breasts, as they are worn in Spain to this day, and this attracting the derisive attention of the irrepressible London street boy of the period, the two gentlemen were soon surrounded by a hooting crowd, who wanted to know what they meant by wearing so outlandish an adornment, and tried to strip the offending coats from their backs. The affair nearly ended in bloodshed, and the Spaniards had to fly for their lives. The very few Spanish ladies who came with Philip were as resentful as their spouses, and we are told that

Donna Hieronima de Nararra and Donna Francisca de Cordoba have decided not to wait upon the queen, as there is no one to speak to them at court, these English ladies being so badly behaved; and the duchess of Alba will not go to court again, as she has been so discourteously treated.

With all this grumbling, however, the country itself extorted the admiration of the visitors: the books of chivalry, we are told, have only stated half the truth. The palaces, rich and splendid with the unballowed spoils of the monasteries; the flowery vales, gushing fountains, enchanted woods, and lovely houses far exceed even the descriptions in 'Amadis ;' but there are 'few Orianas and

25 The Spaniards had to be lodged in the halls of the city gailds. 
many Mavilias amongst the ladies,' and the romancers have said nothing about the strange, uncouth beings who inhabit the enchanting land. 'Who ever saw elsewhere a woman on horseback aloneand even riding their steeds well, and as much at home on their backs as if they were experienced horsemen?' And after confessing the beauty of the country itself the narrator concludes that the disadvantages outweigh the advantages, and wishes to God that he had never seen the place or the sea that led to it. And things got worse as time went on. The Londoners themselves were in an exaggerated panic, that explains their hard treatment of their guests. The author of the 'Chronicle of Queen Mary,' who lived in the Tower of London, and faithfully set down from day to day the news he heard, reflects the terror inspired by the presence of Philip's suite in the capital. We have seen that at the utmost the number of Spaniards of all ranks who landed from the fleet did not exceed 500 , of whom four-fifths had left for Flanders and Spain before the king entered London, and yet the diariat, writing about this time, says : 'At this tyme ther was so many Spanyerdes in London that a man shoulde have mett in the stretes for one Inglisheman above iiij Spanyerdes to the great discomfort of the Inglishe nation. The halles taken up for Spanyerdes.' And again, as showing how complete was the panic, fomented, no doubt, by Noailles and the protestants, there is an entry of 8 September as follows: "A talke of XII thowsand Spanyerdes coming more into this realme, they said to fetch the crowne.' It is not surprising, with such a feeling as this current in the city, that the courtier's next letter, written from London on 2 October, should be more despondent than ever. They were all ill and home-sick; some had almost died, and the country did not agree with them.

God save us and give us health, and bring us safely home again. Tho country is a good one, but the people are surely the worst in the world. I verily believe if it were not for the constant prayers and processions for us in Spain we should all have been murdered long ago. There are slashings and quarrels every day between Englishmen and Spaniards, and only just now there was a fight in the palace itself, where several were killed on both sides. Three Englishmen and a Spaniard were hanged for brawling last week. Every day there is some trouble . . . God help us, for these barbarous, heretical people make no account of soul and conscience; disobey God, disregard the saints, and think nothing of the pope, who they say is only a man like themselves and can have no direct dominion orer them. The only pope they recognise is their sovereign.

The futility of the marriage from a national point of view rankled in the breasts of the disappointed courtiers as much as did their personal discomfort. They felt that the trouble they had undergone and the humble pie they had eaten had added nothing to the power of their country or their sovereign, and their prevailing 
idea was how soonest and best to wash their hands of an angrateful and profitless business in which all their sacrifices had been in vain.

We Spaniards [says the narrator] move about amongst all these Englishmen like so many fools, for they are such barbarians that they cannot anderstend us, nor we them. They will not crown the king nor recognise him as their sovereign, and say that he only came to help govern the kingdom and beget children, and can go back to Spain as soon as the queen has a son. Pray God it may be soon, for he [Philip] will be glad enough, I am sure, and our joy will be boundless to be away from a land peopled by such barbarous folk. The king has forgiven the queen 2,250,000 ducats she owed him, and has distributed 80,000 ducats a year in pensions to these lords of the council, to keep them in a good humour. All this money is taken out of Spein. A pretty penny this voyage and marriage have cost $\mathrm{us}$, and yet these people are of no use to us after all.

Bitter disappointment is the note struck all through. The English lords who had been so heavily bribed were ready enough to take all they could get; but they were as patriotic as they were greedy, and did not sell their country's interests for their pensions. Renard for once had made a mistake. He was ready to assent to any conditions the English liked to propose on paper, trusting to the personal influence of Philip on his queen after the marriage wa's effected. But he forgot that the queen herself was a mere puppet in the hands of her nobles, as the narrator I have quoted soon discovered, and, whatever ascendency the young bridegroom might obtain over his half Spanish bride, her councillors, from the stern Gardiner downwards, were Englishmen before everything, to whom the overweening power of the emperor had been held up as a terror since their childhood. And so the whole splendid plot failed, and the magnificent nuptials had hardly been forgotten before Philip, recognising that his sacrifices had been in vain, and that he could never rule in England, made the best of an unfortanate speculation, and with all gravity, courtesy, and dignity left Mary to die of a broken heart, alone, disappointed, and forsaken.

Martin A. 8. Hume. 